\title{
CUATRO POEMAS PARA UNA LAGARTIJA EN UN DÍA CUALQUIERA
}

\section{El día}

Estoy tirado al sol

de cara al aire

se me quema la piel

se me atropella la cabeza

de pensarte.

Las olas van y vienen

se van, lo sé

y no son las mismas

las que vuelven

aunque yo quiero imaginar

que son las mismas

que el tiempo con el sol

$\mathrm{y} \sin \mathrm{ti}$

no les pone

la panza verde a ellas

como a mí

que no dejo de ser

una inhumana lagartija. 


\section{Trastoque de la tarde}

Trepo por las paredes

viajo por el jardín

donde la tarde es fresca

y las ideas son húmedas.

Le doy mi corazón

que es pequeñísimo

a una flor

y conquisto una mosca con mi lengua.

Dejo mi sangre fría que fluya

que se acostumbre a ti

que te resista.

Luego avanzo con calma

cruzo sin prisa

el camino de espinas del rosal

que no me hará en la panza

ni cosquillas.

Pero tú

solo tú

me mirarás

desde la cima

con desdén

y me harás recodar

mi abrumadora condición de lagartija. 


\section{Pedradas de pasión}

Me corretean los recuerdos

por las calles, no descanso, el sol curte mi piel y mis patas para que pueda yo arrastrarme por la costra de asfalto hasta el mar impasible de los deseos. Tú no me encontrarás, yo llegaré a la noche antes de lo previsto y comeré de su silencio y anidaré en su ombligo y no regresaré para buscarte y traerte conmigo y si es que los recuerdos me siguen correteando arrojaré pedradas de pasión sobre sus lomos tibios y si se recuperan como milagro de nuestro antiguo, absurdo $\mathrm{y}$ torpe idilio entonces solo así tal vez vuelva para rondar tu indiferencia con mis vidriosos y cansados ojos fijos. 


\section{Nocturno}

\section{Derrumbado}

en el centro de este día

me detengo,

no soy

ni siquiera el testigo

ni siquiera la víctima

de aquello que sueñas conseguir

entre las prendas íntimas

de tu juego.

Mira que no soy tú

tú eres lo que aseguran

que le da por cambiar

tú eres camaleón

lagartija ancestral

$y$ es que de noche te pareces

tanto a la noche

que la luna te llora

sus lágrimas de luz

y frío te da su aliento sin colores.

Sí, te pareces de noche

tanto a la noche

que hasta yo sufriría si te fueras

si en el amanecer

con la luz

tus pliegues de mujer entre las manos

se me desvanecieran 
CITAM Derechos Reservados.

La reproducción total o parcial de este artículo se podrá hacer si el ITAM otorga la autorización previamente por escrito. 